\title{
Talaq (Divorce) Procedure in the Provisions of Muslim Family and Inheritance Law of Patani Province, Southern Thailand
}

\author{
Mahyidin Hamat ${ }^{1}$, Zuliza Mohd Kusrin ${ }^{1}$, Ezad Azraai Jamsari ${ }^{2}$, \\ Md Yazid Ahmad ${ }^{1}$, Noorsafuan Che Noh ${ }^{2}$ \\ ${ }^{I}$ Department of Syariah, Faculty of Islamic Studies, \\ Universiti Kebangsaan Malaysia, 43600 UKM Bangi, Selangor, Malaysia \\ ${ }^{2}$ Department of Arabic Studies and Islamic Civilization, Faculty of Islamic Studies, \\ Universiti Kebangsaan Malaysia, 43600 UKM Bangi, Selangor, Malaysia
}

\begin{abstract}
This research discusses the implementation procedure of Muslim marriage dissolution in Patani Province of Southern Thailand, specifically execution of talaq (divorce) in Southern Thailand. In the year 1943, the Muslim Family and Inheritance Law in Thailand in force was repealed, and a newly legislated law could not take effect. Muslim law was re-adopted under a new act passed in the year 1946. This research begins from the implementation of marriage dissolution without a Shariah Court in Southern Thailand. Thus, this research examines the concept of marriage dissolution according to Shariah and analyses its implementation in Patani Province, Southern Thailand. The research methodology is analysis of Thai laws and Shariah relating to marriage dissolution.
\end{abstract}

Keywords: Talaq, Divorce, Patani Province, Southern Thailand

\section{INTRODUCTION}

The Thai Ministry of Justice directed that an Islamic bill be the basic reference guide for qadis in conducting court hearings. This law is named 'Lak Kodmai Islam Waduwai Krobkuwa Lae Maradok' (Rules/Procedure of Muslim Law: Family and Inheritance). As quoted from amended articles 1 to 189, the Muslim Family Law Act 1945 (in Malay: Undang-undang Keluarga dan Pusaka Islam, thereafter mentioned as UUKDPI) is divided into three sections: Introduction, Chapters One and Two. Chapter One relates to family law and is subdivided into five sections. Chapter Two concerning inheritance also consists of five sections. In total, the sections contain 230 articles, among which are articles relating to marriage dissolution. The articles on marriage dissolution are divided into two categories. The first category is the introductory section which explains the different kinds of marriage dissolution. The second category explains the articles relating to marriage dissolution, including the definition of talaq (divorce), conditions for validity of talaq, pronouncement of talaq, calculation of talaq, remainder or balance of talaq, talaq raj'i (revocable), talaq ba' in (irrevocable), delegation of talaq rights to a wife (husband giving wife right to talaq), husband appoints representative to talaq, talaq by acceptance of consideration, denial of talaq by payment, conversion of talaq into raj ' $i$ or $b a^{\prime} i n$, right to receive payment in talaq raj ' $i$ or ba'in, negligence in conditional talaq, and fulfilment of conditions of talaq.

\section{TALAQ PROCEDURE IN THAILAND}

There are two ways of ending a marriage by talaq (divorce) in Thailand. The first way is talaq in the presence of the village Imam and the second in the office of the Muslim Religious Committee Council Committee (MRCC) (hereafter mentioned as the Majlis) in certain Thai provinces. After the talaq is confirmed, the Imam or Majlis will issue a divorce certificate to both parties. The Imam or Majlis is required to produce three copies of proof of divorce. The first copy is given to the former husband, the second is for the former wife and the third is for keeping records of documents by the Imam or Majlis (Ahmad Omar 2012). This certificate is considered as a religious but not a valid legal document as compared to other Thai government documents except that it is recognised by the Mahkamah Wilayah (Provincial Court) (hereafter referred to as the Court) (Muhammad Zakee 2007: 94). The Imam and Committee Members of the Majlis in each province are considered as not acting in the capacity of a registrar as understood by society nor are they categorized as civil servants in the Thai Penal laws. By virtue of the Administration of Islamic Organizations Act 1997, the Imam and Committee Members of the Majlis have the authority to issue but not to register marriage and divorce certificates. Thus, in discharging their responsibility, they are not accountable for any consequence which may 
ensue. As a result, a minority of divorced couples file their legal claims once more at the Court to reaffirm that their divorce have been approved by the Imam or Majlis. When legal claims are accepted by the Court, Dato' Yutitham will execute provisions in the UUKDPI to confirm and declare that talaq has been executed according to Muslim law. Dato' Yutitham is a judge or the person who hears cases. The position of Dato' Yutitham was first established about the year of Rattanakosin (R.S) 120 (B.E. 2444). At the time, Dato' Yutitham was known as Tok Kadi. Acording to legal provisions, Dato Yutitham plays the role of deciding cases relating to family and inheritance issues.In addition, talaq sometimes occurs in the homes. The UUKDPI does not explain in detail on the procedure to execute talaq, thus a husband may divorce her any time, any place and for any reason. The process of divorce in the border provinces of Southern Thailand may be understood in the diagram below:

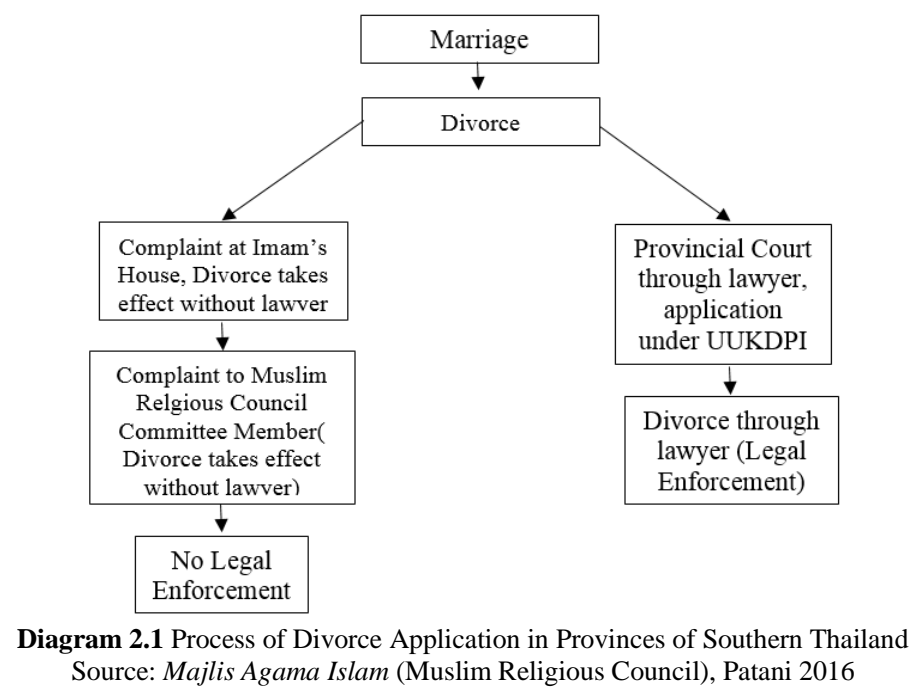

Diagram 2.1 shows two ways of marriage dissolution. First, when talaq is pronounced at home, the couple will inform the Imam who will then issue a certificate of divorce. The divorce certificate may not be used as prima facie evidence (based on first impression and accepted as correct until proven otherwise) in claiming rights in marriage and divorce unless the husband files a civil suit in the Court. Second, after application for divorce is filed in Court, the Court will examine whether the documents are complete or otherwise. If incomplete, the court officer will return it to the plaintiff's lawyer for rectification. After the completed documents are filed and registered, the court will decide on the date for trial and reading. The process at the Court of border provinces of Southern Thailand may be illustrated as in the diagram below:

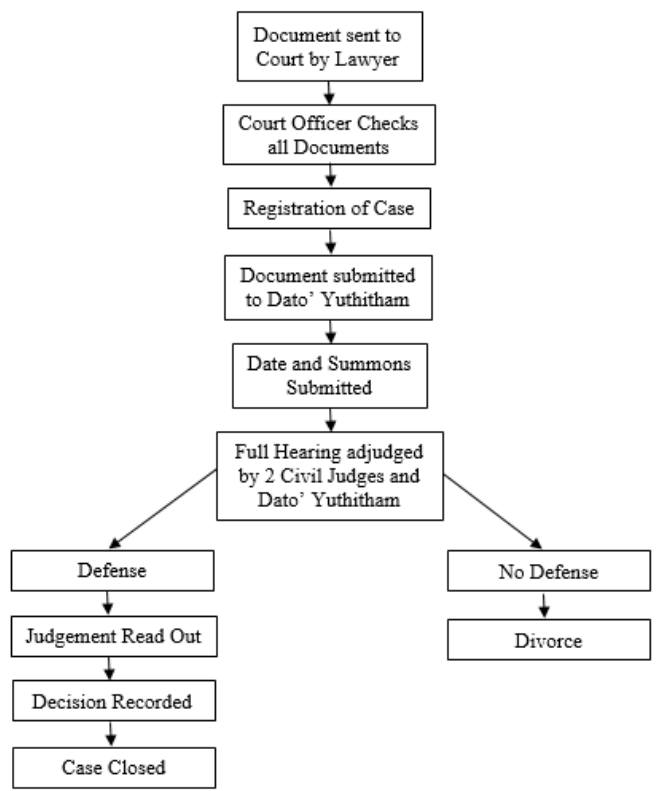

Diagram 2.2 Divorce Application Process at Patani Provincial Court Source: Mahkamah Wilayah (Provincial Court), Patani 2013 
There is absence of provision for registration under UUKDPI whether for registration of talaq or relating to such divorce procedure under UUKDPI. A wife possibly might not even know that she has been divorced until informed by her spouse. In a case study in Thailand, each application for divorce filed in the Court of the four border provinces was done by the wife, because the husband may simply pronounce talaq without having to make a divorce application to Court. For the purpose of divorce registration in the case of Muslims, the Thai Civil and Commercial Law Code 1934, Book V is applicable to both Muslims and Buddhists alike. This is due to the absence of the office of Registrar of Muslim Marriage and Divorce. The usual practice is for the divorce applicant to be present at the Office of the District Officer.In the case of Muslim applicants, all applications for talaq must be first submitted to the local Imam where the applicant resides (Administration of Islamic Organizations Act 1997). After the Imam has accepted the application, the applicant must fill up a divorce application form for the Majlis. The Majlis will request the couple to come together with the Imam. If the Majlis is satisfied that the marriage cannot be mended anymore, Majlis will request the husband to pronounce talaq (Ahmad Omar 2011). Majlis will then issue a divorce together with a record of reasons or causes for pronouncement of talaq. A copy of the certificate is kept by the Majlis as reference. However, if the husband refuses to pronounce talaq, Majlis will request him to pronounce divorce through demand for payment after the amount is agreed upon by both parties.As previously stated, in the four border provinces talaq may take place in the presence of the Imam, Majlis Committee of or before Dato' Yuthitham in the Court. This is so because Dato' Yuthitham is appointed by the government to resolve disputes related to family affairs for Muslims in the four provinces of Narathiwat, Yala, Patani and Satul. Instead, in practice, a minority of Dato' Yuthitham are appointed by the Majlis to be Committee Members in the Majlis. In such cases, marriage and divorce may be implemented before him in the capacity of a Majlis member and not as a judge. This double responsibility will create more problems for Muslim plaintiffs in Southern Thailand as the actual responsibility of a Dato' Yuthitham is to hear and decide cases in Court.

\section{CONDITION FOR PRESENCE OF WITNESS UNDER UUKDPI}

UUKDPI has no provision making it a condition that talaq requires the presence of witnesses. This condition is taken from the Holy Qur'an and Sunnah of the Prophet (pbuh) which specifies this rule in surah alTalaq, verse 2 as in the following meaning: "And take for witness two persons from among you, endued with justice, and establish evidence (as) before Allah". The command, "And take for witness two persons" in this verse shows the obligation in reference to whether talaq or its revocation.In terms of language, the command to take witnesses in the verse refers more precisely to talaq, primarily because the whole verse discusses talaq and not revocation. Based on the abovementioned verse, Sunnis hold the opinion that at the time of pronouncement in divorce, the presence of witnesses is required (al-Qurtubi 1996, 2:134). Nevertheless, it is not an essential condition of divorce. Sunnis allow divorce without the presence of witnesses because it is the absolute right of the husband which does not require witnesses. In contrast, Shi'ites and Zahiris differ in opinion from the Sunnis, because they require witnesses present for divorce to be valid (Ibn Hazm 1970, 10:185). They base their opinion on the above verse and also the Prophet's (pbuh) Sunnah.It was related by Mu'arrif ibn 'Abd Allah that 'Imran ibn Husayn said of a person who divorced his wife and later had marital relations with her. There was neither witness for the divorce nor for its revocation. He said: "You divorced in contradiction to Sunnah. Call someone to be witness for your divorce and its revocation and do not repeat it" (al-'Azim Abadi 1990, 5:181).

It was found that in cases of Muslim divorce in Southern Thailand, many husbands choose to pronounce divorce at home without getting the views of the Conciliation Committee as arranged by the Majlis or the office of Dato' Yuthitham. Such situations occur because they do not want third party intervention and sometimes are encouraged to do so by the opinions and advice of family members. Husbands also do so to keep the divorce process simple, less costly and less lengthy in time. As a consequence of this understanding and attitude to take the easy way out, many related matters after divorce are left unaddressed, such as matrimonial property, custody (hadanah) rights, maintenance (nafaqa) during 'iddah (waiting period) and muta'ah (compensation or consolation gift). This ultimately has a negative effect, particularly to the divorced wife because her rights are unprotected by any party.Divorce shall not be pronounced except in the presence of the village Imam or Dato' Yuthitham. For the Majlis, talaq cannot be allowed unless the couple have gone through arbitration at the office of Dato' Yuthitham or of the Majlis. However, if the couple fails to comply with this procedure, it is considered an offence and a fine can be imposed under UUKDPI.

\section{SHIQAQ UNDER UUKDPI}

The Holy Qur'an does not approve of shiqaq. Al-Shawkani (1994) stated that the word shiqaq was derived from shaqq which means divided into two The harfiyyah (meaning) of shiqaq is quarrel or hostility. Therefore, the word shiqaq connotes a tense conflict between a couple which can destroy the bond of a strained marriage. 
Based on the above definition, shiqaq reflects the differences in opinion which arise between spouses which may lead to domestic conflict. For example, a couple constantly fight until they reach a stage when they cannot live peacefully together. However, it has to be remembered that not all shiqaq lead to divorce. What leads to divorce is the diffrence in opinion. If a couple cannot agree between them and separation becomes more likely, the authority (judge) is allowed to appoint two males as mediators to seek reconciliation and keep good relations between them while managing them professionally at the same time (Ghaanim 1983, 1:55).

The Holy Qur'an has laid down the guideline relating to procedure such as the appointment of a person with authority to make decisions in cases of misunderstanding. The appointed person is usually known as Hakam. This matter is stated in surah al-Nisa', verse 35, as in the following meaning: "If ye fear a breach between them twain, appoint (two) arbiters, one from his family, and the other from hers; if they wish for peace, Allah will cause their reconciliation: For Allah hath full knowledge, and is acquainted with all things".

The verse stated above shows that Allah SWT also outlines the procedure which needs to be followed when misunderstanding occurs between spouses. The appointment of an arbitrator from both sides is necessary. The first function of the Hakam or arbitrator is to open the way for conciliation and bring about harmony between the spouses. If the endeavour succeeds, the couple will continue to live together as husband and wife.

\section{CONCILIATION BODY}

It is interesting that both the provincial institutions of the Mahkamah Wilayah (Court) and the Majlis Agama Islam Wilayah (Majlis) agreed to set a Conciliation Body for two purposes: (a) to avoid the breakdown of marriage, and (b) to maintain the relationship between the plaintiff and the defendant after the divorce. From its inception, the primary function of the Majlis is to act as mediator or intermediary in family and inheritance disputes. The Islamic Religion Act 1945 (Akta Agama Islam B.E.2488/A.D.1945) later recognised this honorable work. This Act, named as Royal Act is related to the Administration Of Islamic Organizations (B.E.2540/A.D.1945). In the Royal Act, article 26(1) states that: "The Provincial Muslim Religious Council has the authority for the compromise of disputes relating to family and inheritance based on exchange".It shows that this Act does not state any prerequisite qualifications for appointment of concilators or arbitrators and the prescribed procedure to conduct conciliation sessions. It can be inferred that the Majlis uses a conventional approach. In Narathiwat, the usual practice is for Majlis to direct that both parties seek reconciliation before a Conciliation Committee when a complaint is reported. If the committee is unable to reconcile the two parties to continue their married life together, the committee will advise or request the husband to pronounce divorce. As has stated by the Majlis regarding the process of appointing Hakam or arbitrators, the Conciliation Body in its implementation is not inconsistent with the importance of arbitrators as outlined in al-Qur'an.

Acknowledging the importance of the Hakam institution, the Minister of Justice has issued rules for the administration of the Mahkamah Keadilan (Court of Justice) relating to the conciliator of disputes (B.E.2544/A.D.2001). According to this ruling, the qualifications of the Conciliation Committee are as follows:

1. The conciliator is required to have basic knowledge of science, economics, psychology, sociology and law;

2. Aged 25 years and above;

3. A person of superior moral character;

4. Must not have been declared as incompetent by the Court; and

5. Never been sentenced for imprisonment, at the least for self-neglect.

The rules and qualification of the Conciliation Committee do not meet the true qualifications required in Shariah. Looking at the first prerequisite, it does not emphasize and give priority to religious knowledge, so that a person ignorant of religious law may be appointed as Hakam. Likewise, regarding the fourth and fifth prerequisites and qualification, an incompetent and negligent conciliator in handling disputes in a case will not be held accountable. The attitude of a Hakam who is unqualified and does not fit into the category of an appropriate Hakam may cause a small case to be big and complicate the situation more. The responsibility of a conciliator is to reconcile and be the mediator between disputing parties. In executing his duties, no coercion is permitted. The conciliation process is conducted before a case is brought to court. If the Hakam fails to reconcile or be a intermediary or mediator, the Hakam on duty will send a report to the Court.Based on the above discussion, it is said that both institutions diligently work to resolve problems related to marriage disputes through conciliation to avoid marriage breakdown. The ability of the Conciliation Body to act effectively depends on the Hakam's role during the conciliation process. In view of the Hakam's qualifications not fulfilling the Shariah requirement to be knowledgeable about Muslim family affairs, this might cause difficulty in achieving the goal of reconciliation by Hakam. This situation may probably cause the issue of broken marriages to become severe and chronic in the four southern provinces of Thailand.Generally, UUKDPI does not provide any articles which touch on the conciliation process and appointment of arbitrators or conciliators (Hakam) or procedure to be followed despite these being clearly stated in the Holy Qur'an. The procedure used by the Majlis in Southern Thailand, since its inception, is that when a husband or wife approaches the Majlis for divorce, the Majlis will endeavour to reconcile the couple. Frequently, the Majlis will hear the complaints from both parties 
and postpone the case for some weeks after the first reading is done. The purpose is to give time should there be space for reconciliation between the spouses. If the conflict worsens, Majlis will allow divorce to be pronounced by the husband in the presence of the Majlis member who is responsible and the pronouncement will be recorded. Then a certificate of divorce will be issued to both parties (Ahmad Omar 2010).In the case of Ramlah Haji Hamid (Religious Council Committee Patani 2011), a Conciliation Body was appointed to find ways to reconcile but the parties could not reach an understanding. The wife said that she did not wish to live with her husband anymore. However, the husband refused to pronounce talaq pronouncement on his wife. The Conciliation Committee later requested the husband to pronounce talaq by khul:

Generally, the implementation of the Islamic principle based on shiqaq is also used by the Court as a basis for marriage dissolution such as, for example, cases of humiliation, beating and so on. Article 70 of UUKDPI, inter alia, states: when a husband causes injury to a wife, for example, humiliating or beating without reasonable cause, in such a case, the wife may file an application and request the court to issue a separation order. Further, UUKDPI outlines that the Court shall request the wife to stay temporarily with a just person. UUKDPI also stipulates that the wife's right to maintenance while staying with the said just person, is the husband's responsibility.Thus it is clear that UUKDPI discusses the concept of shiqaq only generally, by briefly stating two basic divorce grounds which enable a wife to file an application should her husband hurt her, whether by humiliating or by beating her. If it is proven in Court, the husband will be forced to separate from her. Then, the Court will appoint a just person to look after the wife's welfare.UUKDPI emphasizes on the appointment of a just person to look after the wife's welfare, and not the appointment of an arbitrator as stated in the Holy Qu'ran. As introduced by the Majlis in the four southern provinces, Dato' Yuthitham has the authority to be a Hakam or appoint another person, if necessary, as an arbitrator or Hakam, especially if there occurs continuous fighting between the two parties. An Arbitration Body Council is formed prior to the divorce pronouncement by the husband. In Narathiwat and Patani, the usual practice is that the Majlis will direct the couple to refer to the Conciliation Committee to seek reconciliation. If the Conciliation Committee fails to persuade the couple to live together again, the Majlis will advise the husband to make a divorce pronouncement (Ma-Useng Pador 1993).The above explanation shows that the conciliation process and appointment of arbitrators is important to avoid marriage breakdown. This approach needs to be implemented in UUKDPI. In any case, where the couple seeks separation, the husband or wife must apply to the Court and the Court will be responsible to attempt their reconciliation. However, if all efforts by the Court are unsuccessful, the couple is allowed to separate.

\section{CONCLUSION}

This research discusses matters related to talaq procedure according to the legal provisions under the Muslim Family and Inheritance Law (UUKDPI) in Thailand as well as the pronouncements for talaq, both sarih (clear and specific) and kinayah (figurative or indirect); the stipulation that the husband's right to exercise talaq shall not exceed three times if he is a free man, and if he is a slave, not more than twice. Talaq can be raj $i$ (revocable) if the husband divorces his wife the first or second time only, and can be ba'in (irrevocable), whether ba'in sughra or ba'in kubra. In this category it is also stated that other than the husband personally declaring divorce, the right to talaq may also be given to the wife or the husband may appoint a certain representative to divorce the wife, or the husband divorces his wife by accepting payment (khulu') from her, or when a husband violates a divorce agreement or condition set by him, known as talaq by ta 'liq.

\section{REFERENCES}

[1] Ahmad Omar Chapakia. 2010. Prosedur Talaq di Bawah Peruntukan Undang-undang Keluarga dan Pusaka Islam Wilayah Patani [Talaq Procedure under the Patani Muslim Family and Inheritance Law] (UUKDPI). 28 August.

[2] al-'Azim Abadi, Shams al-Haqq. 1990. 'Awn al-Ma 'bud Sharh Sunan Abi Dawud. Vol. 5-6, Beirut: Dar al-Kutub al-Ilmiyyah .

[3] Ali, Maulana Muhammad. n.d. The Religion. New Delhi: S. Chand and Co.

[4] Ghaanim, Saalih. 1983. Marriage breakdown: Comparative view. IIUM Law Journal 1(1): 55-60.

[5] Ibn Hazm, Abu Muhammad 'Ali ibn Ahmad ibn Sa'id. 1970. al-Muhalla. Cairo: Mustafa al-Babi alHalabi.

[6] Jawatankuasa Majlis Agama Islam Patani [Patani Muslim Religious Council Committee], File No.: 36/B.E 2544 (2001).

[7] Kanun Undang-Undang Sivil and Komersil Thai [Thai Civil and Commercial Law Code 1934], Book 5, Article 1514.

[8] Kanun Undang-Undang Sivil and Komersil Thai [Thai Civil and Commercial Law Code 1934], Book 5, Article 1516(1). 
[9] Kanun Undang-Undang Sivil and Komersil Thai [Thai Civil and Commercial Law Code 1935], Book 5, Article 1516 (1).

[10] Kes Mahkamah [Court Cases] Wilayah Narathiwat, Civil Suit No: 53/B.E.2543 (2000).

[11] Kes Mahkamah [Court Cases] Wilayah Patani, Civil Suit No: 452/B.E. 2546 (2003).

[12] Keputusan Mahkamah Tinggi Thai [Thai High Court decisions], 1151/B.E. 2545 (2002).

[13] Mahkamah Sivil [Civil Court] Wilayah Patani, Civil Suit No: 250/ B.E2543 (2000).

[14] Kes Mahkamah [Court Cases] Wilayah Narathiwat, Civil Suit No: 14/B.E.2544(2001).

[15] Kes Mahkamah [Court Cases] Wilayah Patani, Civil Suit No: 2543 (2000).

[16] Kes Mahkamah [Court Cases] Wilayah Patani, Civil Suit No: 389/B.E.2538 (1995).

[17] Ma-Useng Pador Kampong. 1993. Peranan Majelis Ugama Islam Narathiwat dalam Mengembangkan Islamiyah Di Propinsi Narathiwat Thailand Selatan [The Role of Muslim Religious Council in Propagating Islam in Narathiwat Province, Southern Thailand]. Master Dissertation, Institut Agama Islam Negeri Sunan, Yogyakarta, Indonesia.

[18] Muhammad Zakee Cheha. 2007. Undang-Undang Keluarga Pada Abad 21: Cabaran dan Masa Hadapan [Family Law in the 21st Century: Challenges and the Future], Seminar Undang-Undang Keluarga, Crown Princess Hotel, Malaysia,16-17 January.

[19] al-Shawkani, Muhammad Ali. 1994. Nayl al-Awtar. Vol. 1. Beirut: Dar al-Kutub al-'Ilmiyyah.

[20] al-Shayrazi, Ibrahim ibn 'Ali al-Fayruz Abadi. 1995. al-Muhazzab fi Fiqh al-Imam al-Shafi 'i. Beirut: Dar al-Kutub al-'Ilmiyyah. Vol. 2, p. 134.

[21] Peraturan dan Kaedah Pentadbiran Mahkamah Keadilan dalam Perkara Perdamaian Pertikaian [Rules and Methods of Courts of Justice in the Matter of Dispute Conciliation], Peraturan no: 28.

[22] Peraturan dan Kaedah Pentadbiran Mahkamah Keadilan dalam Perkara Perdamaian Pertikaian [Rules and Methods of Courts of Justice in the Matter of Dispute Conciliation], Peraturan no: 32(1)(2).

[23] Peraturan dan Kaedah Pentadbiran Mahkamah Keadilan dalam Perkara Perdamaian Pertikaian [Rules and Methods of Courts of Justice in the Matter of Dispute Conciliation], Peraturan no: 32(3).

[24] al-Qurtubi, Muhammad ibn Ahmad. 1996. al-Jami`li Ahkam al-Qur'an. Beirut: Dar al-Kutub al'Ilmiyyah. Vol. 3, pp. 23-24. 